\title{
Exchange networks from close-up: The case of Lipari obsidian
}

\author{
Andrea Vianello ${ }^{1}$, Robert H. Tykot ${ }^{2}$ \\ 1. Independent researcher. 19 May Road, Sheffield, S6 4QF, U.K. Email: a_vianello@hotmail.com \\ 2. University of South Florida. Department of Anthropology, 4202 East Fowler Ave, SOC107, Tampa, FL \\ 33620-7200, U.S.A. Email: rtykot@usf.edu
}

\begin{abstract}
:
A systematic study on obsidian tools in Calabria and Sicily carried out by the authors have revealed the uniqueness in the patterns of production, exchange and consumption of Lipari obsidian. The study has concentrated on the Middle Neolithic primarily, with other Neolithic and Bronze Age contexts recognised at a later stage in the research since many contexts, especially in Sicily, have been excavated by pioneering archaeologists, some over a century ago, or were mislabelled. The chronology is Early Neolithic to Early Bronze Age, with very few materials dating Middle Bronze Age. A review of chronological contexts is in progress, which spans from the 6th millennium BC to the end of the 2nd millennium BC. The typology of obsidian tools is very homogenous, the vast majority of used tools are small blades, bladelets and sharp flakes; there is negligible variance across time; and Lipari obsidian is preferred over other sources. The patterns of the exchanges are also unique, revealing two major types of redistribution of obsidian, one particularly intriguing because it is quite organized with a single source in Lipari, prominent and reminiscent for its stability and reach of Bronze Age redistribution dynamics associated with hierarchical societies. We present here some observations on patterns substantiated by the archaeological record, and consider possible scenarios that can explain them. This work provides an update on progressing research and reveals aspects that will need further investigation, focusing on the patterns identified so far and possible explanations. More work is certainly needed to produce a working model, but the unusual patterns deserve some attention on their own, unencumbered by an overarching explanatory model. In particular, we want to assess the Neolithic redistribution pattern suggestive as typical of hierarchical polities, and contextualize it to the specific situation of Neolithic Lipari.
\end{abstract}

Keywords: obsidian; Italy; Lipari; exchange; trade

\section{Introduction}

Artifacts made of Lipari obsidian were exchanged across the Central Mediterranean from the Neolithic period to the Bronze Age. Lipari is one of the Aeolian Islands, small and rich in obsidian, which was easily found. The particular characteristics of the material, shiny and very sharp, were likely the reasons for its diffusion in antiquity. Obsidian is found in several places in the Mediterranean region (Tykot 2011), and there are three other important island

Published by the School of History, Classics and Archaeology, University of Edinburgh ISSN: 2055-0472. URL: http://journals.ed.ac.uk/lithicstudies/

This work is licensed under a Creative Commons Attribution 2.5 UK: Scotland License. 
sources within the distribution area of Lipari obsidian: Monte Arci in Sardinia, tiny Palmarola in Campania, and Pantelleria, a small but inhabited island located south of Sicily. The obsidian from Lipari can be black or grey, with or without phenocrysts, and varying in translucency; Palmarola obsidian is similar in color but mostly opaque and without phenocrysts. Pantelleria obsidian is dark green and mostly opaque. There also are differences in the size of the natural blocks available, and in the physical properties which affect percussion size and success, and the brittleness of the tools produced. The distribution of Lipari obsidian encompasses a remarkably large area, which is centered on the Italian peninsula, with large amounts found in southern Italy and Sicily (Figure 1, Table 1).

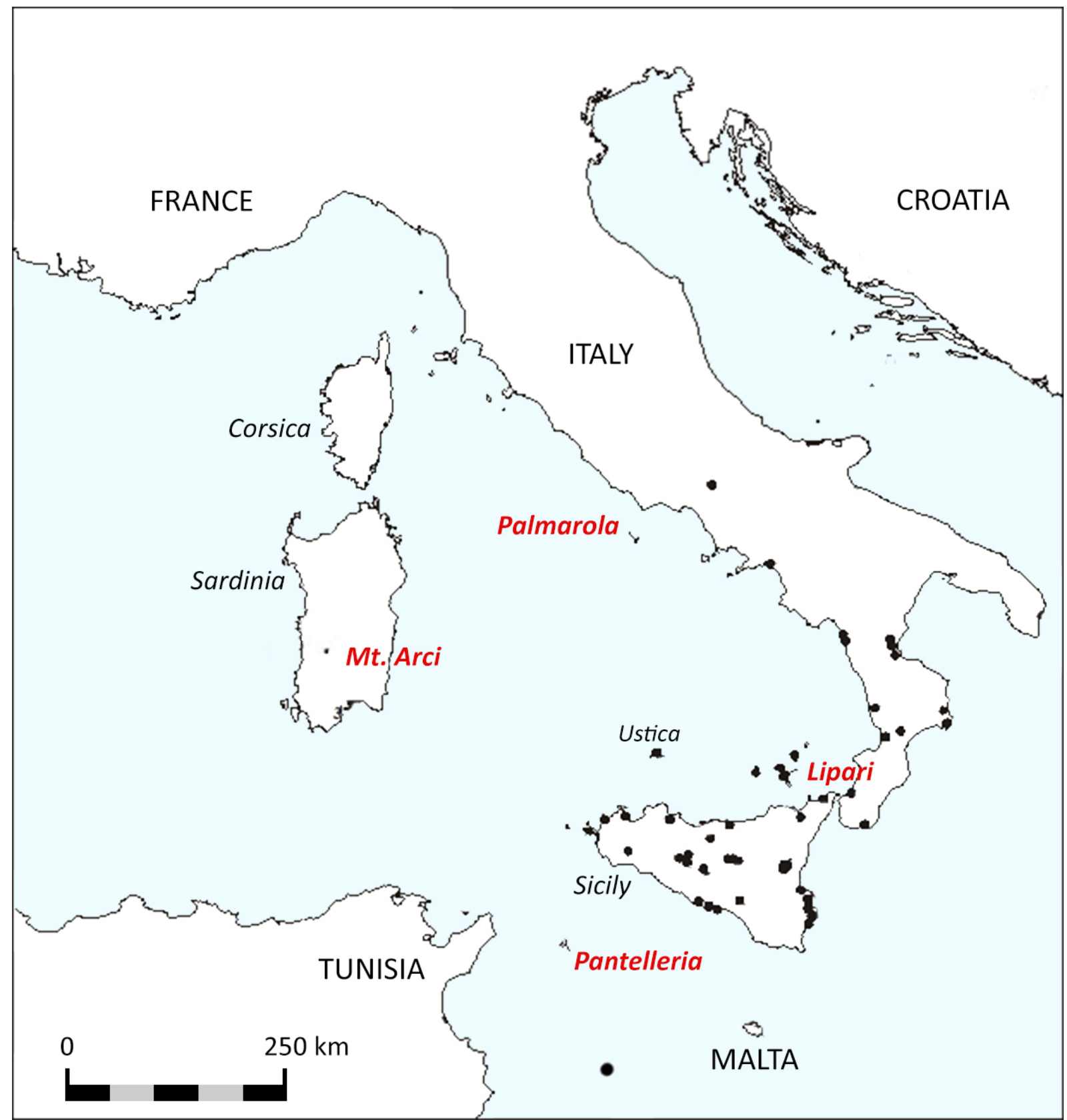

Figure 1: Map of the area being investigated. The four main sources of obsidian in Italy are marked. The sites indicated are those listed in Table 1. Most sites yielded almost exclusively Lipari obsidian, with the exceptions a few coastal sites facing Pantelleria in the western part of Sicily. 
Table 1: List of artifacts analyzed with pXRF by authors, organized by site. Sites with at least some Bronze Age artifacts are indicated. All artifacts listed here were analyzed, with high numbers particularly from contexts in eastern Sicily and Ammerman's surveys of Calabria.

\begin{tabular}{|c|c|c|c|}
\hline Region & Site & No. of Artifacts & Bronze Age \\
\hline Calabria & Acconia & 170 & $x$ \\
\hline Calabria & Bova Marina & 197 & \\
\hline Calabria & Campolongo & 2 & \\
\hline Calabria & Capo Alfiere & 150 & \\
\hline Calabria & Casa Trogena & 6 & \\
\hline Calabria & Crotone & 331 & $x$ \\
\hline Calabria & Crotone Mandria Vituso & 14 & \\
\hline Calabria & Favella & 44 & \\
\hline Calabria & Grotta del Romito & 11 & \\
\hline Calabria & Grotta dellla Madonna & 29 & \\
\hline Calabria & Piani della Corona & 141 & $x$ \\
\hline Calabria & San Leonardo di Cutro & 6 & \\
\hline Calabria & Saracena & 467 & $x$ \\
\hline Calabria & Serra D'Aiello & 130 & \\
\hline Calabria & Sibari & 253 & $x$ \\
\hline Calabria & Timpone - Steccato Cutro & 1 & \\
\hline Calabria & Tiriolo & 59 & \\
\hline Calabria & Umbro & 1 & \\
\hline Campania & Alburui (Fra. Liberto) & 7 & $x$ \\
\hline Campania & Ausino & 21 & $x$ \\
\hline Campania & Capri & 6 & \\
\hline Campania & Grotta della Serratura & 1 & $x$ \\
\hline Campania & Olevano & 6 & $x$ \\
\hline Molise & Venafro & 132 & $x$ \\
\hline Sicily & ‘Npisu & 14 & \\
\hline Sicily & Agrigento & 8 & \\
\hline Sicily & Aidone & 42 & \\
\hline Sicily & Boccadifalco - Villa Gregoretti & 9 & \\
\hline Sicily & Boccadifalco Palermo & 3 & \\
\hline Sicily & Calaforno & 9 & \\
\hline Sicily & Capreria & 13 & \\
\hline Sicily & Casa Bastione & 68 & \\
\hline Sicily & Casalicchio & 77 & \\
\hline Sicily & Castelbuono & 100 & \\
\hline Sicily & Castelluccio & 1 & $x$ \\
\hline Sicily & Castelluzzo di Mazara del Vallo & 1 & \\
\hline Sicily & Casteltermini (Loc. La Grazia) & 35 & \\
\hline Sicily & Cava Canabarbara & 10 & \\
\hline Sicily & Chiusilla & 3 & \\
\hline Sicily & Contrada Caduta (Licata) & 52 & \\
\hline Sicily & Contrada Diana & 204 & \\
\hline Sicily & Contrada Orto del Conte & 70 & \\
\hline Sicily & Cozzo del Pantano & 1 & \\
\hline
\end{tabular}




\begin{tabular}{|c|c|c|c|}
\hline Region & Site & No. of Artifacts & Bronze Age \\
\hline Sicily & Culunnedda & 3 & \\
\hline Sicily & Enna - Contrada Agnese & 2 & \\
\hline Sicily & Enna - Masseria Giresi & 2 & \\
\hline Sicily & Filo Braccio (Filicudi) & 50 & \\
\hline Sicily & Fiumedinisi & 4 & \\
\hline Sicily & Fontana di Pepe & 4 & \\
\hline Sicily & Fontanazza Monte Grande & 50 & \\
\hline Sicily & Fontanazza Monte Grande Grotta 2 & 1 & \\
\hline Sicily & Gela & 5 & \\
\hline Sicily & Gela Manfria & 1 & \\
\hline Sicily & Grotta Calafarina & 9 & \\
\hline Sicily & Grotta Corruggi & 2 & \\
\hline Sicily & Grotta del Conzo & 1 & \\
\hline Sicily & Grotta d'Oriente & 26 & \\
\hline Sicily & Grotta Giovanna (Siracusa) & 3 & \\
\hline Sicily & lannicu & 3 & \\
\hline Sicily & Isola di Ognina & 140 & \\
\hline Sicily & La Muculufa 1 & 20 & $x$ \\
\hline Sicily & Lampedusa & 58 & \\
\hline Sicily & Levanzo & 17 & \\
\hline Sicily & Lipari - Trip Villard & 4 & \\
\hline Sicily & Lipari F-1-I/5 & 5 & \\
\hline Sicily & Malpasso & 4 & \\
\hline Sicily & Matrensa & 124 & \\
\hline Sicily & Megara Hyblea & 127 & \\
\hline Sicily & Menta & 3 & \\
\hline Sicily & Milena & 2 & \\
\hline Sicily & Mizzebbi & 5 & \\
\hline Sicily & Monte Sallia & 1 & \\
\hline Sicily & Monte San Paolillo & 3 & \\
\hline Sicily & Northwestern Sicily & 2 & \\
\hline Sicily & Paceco Grotta Maiorana & 19 & \\
\hline Sicily & Palazzola Acreide & 4 & \\
\hline Sicily & Palma di Montechiaro (Licata) & 44 & \\
\hline Sicily & Panarea & 1 & \\
\hline Sicily & Partanna & 18 & \\
\hline Sicily & Poggio Rosso & 22 & \\
\hline Sicily & Pta. Milazzese (Panarea) & 45 & $x$ \\
\hline Sicily & Rinicedda 1 & 205 & $x$ \\
\hline Sicily & Rocca Aquilia & 3 & \\
\hline Sicily & S. Martino & 142 & \\
\hline Sicily & S. Onofrio & 6 & \\
\hline Sicily & San Basilio & 16 & \\
\hline Sicily & San Vito Lo Sapo & 1 & \\
\hline Sicily & Sant'Ippolito & 7 & \\
\hline Sicily & Serra del Palco & 42 & \\
\hline
\end{tabular}




\begin{tabular}{llcc}
\hline Region & Site & No. of Artifacts & Bronze Age \\
\hline Sicily & Serraferlicchio & 6 & \\
Sicily & Stentinello & 141 & \\
Sicily & Tindari & 3 & $\mathrm{x}$ \\
Sicily & Tornambè & 51 & \\
Sicily & Tre Fontane & 62 & \\
Sicily & Ustica - Faraglioni & 307 & \\
Sicily & Ustica - Parrish C.G. Seminara & 129 & $\mathrm{x}$ \\
Sicily & Ustica - San Bartolicchio quarter & 11 & $\mathrm{x}$ \\
Sicily & Ustica - Spalmatore & 28 & $\mathrm{x}$ \\
Sicily & Ustica - Villaggio Cardoni & 96 & $\mathrm{x}$ \\
Sicily & Uzzo & 2 & \\
Sicily & Valdesi & 42 & \\
Sicily & Vallone Inferno & 74 & \\
\hline
\end{tabular}

Through maritime trade following the mid-Adriatic corridor formed by the Gargano promontory, Tremiti Islands, the Palagruža archipelago and the Dalmatian Islands, Lipari obsidian reached Croatia (Tykot 2011). The obsidian also reached Tunisia, enough to be detected at multiple sites, Malta, Corsica, and France (Le Bourdonnec et al. 2015; Thorpe et al. 1984; Tykot \& Ammerman 1997). This distribution results in Lipari obsidian largely covering the full distribution areas of Pantelleria and Palmarola and overlapping in part with the distribution area of Sardinian obsidian. There is little evidence of Pantelleria obsidian except for southern and western Sicily, and other islands including Malta and Lampedusa. There is little evidence for obsidian from Sardinia or Palmarola in most of Calabria and the whole of Sicily, even after a program of systematic sampling in those areas, demonstrating that Lipari obsidian was highly "preferred". Even in western Sicily itself, Pantelleria obsidian accounts for a major part of the assemblages only in Gozo (Malta), on the nearest shores and one well-inland site in Sicily, but reduces its presence steadily, with a negligible number reaching Syracuse, the main harbor on the south-eastern side of Sicily. This is an unusual case for Neolithic exchange networks in the Mediterranean, made more enigmatic by the lack of any distinguishable feature exclusive, at least in the area, to Lipari obsidian.

Separate typological studies have been carried out by Maria Clara Martinelli (1995, and others following) and Kyle Freund (Freund 2014; Freund et al. 2015; 2017), demonstrating the limited repertoire of Lipari obsidian: small blades with sharp debitage and angular waste is virtually all there is, certainly at most sites, and all cores were used to produce small blades and the angular waste that is known from the assemblages. There is no evidence of retouching in most cases. The study on the function of Lipari obsidian, also investigating use-wear traces (carried out by Maria Rosa Iovino (Longo et al. 2000, Tykot et al. 2004)), is progressing, but there is no evidence from preliminary results of any physical or typological reason that could justify the known distribution of Lipari obsidian. Lipari is a small island, in the Neolithic perhaps not even occupied consistently all year round each year, with a modest population. The culture of the Aeolian Islands has been described as polymorphic by Leighton (1999: 73) after recognizing constant new cultural influences that prevented the formation of a local culture. There is only one Neolithic tomb found in the entire island (Bacci 2009: 11) despite several small settlements being found, as well as evidence of a demographic collapse in the Bronze Age. All these aspects suggest an unstable occupation, with the possibility of a tiny resident population (local farming and husbandry was limited) and frequent seasonal visitors connected to the obsidian trade. Its geographic location does not favor the movement of 
artifacts towards Tunisia, which perhaps would have been reached mostly through Pantelleria. Lipari shares the Tyrrhenian Sea with both Sardinia and Palmarola, yet has the least distant open-water travel to mainland Italy, with obsidian easily accessible in large quantities by residents or visitors. Monte Arci is substantially inland in Sardinia, while tiny Palmarola has no drinkable water or permanent residents.

\section{Identifying patterns}

Lipari obsidian was accessible in antiquity from two nearby subsources, Gabellotto Gorge and Canneto Dentro, with the latter more easily accessible from the Castle area, the historical settlement and harbor since Neolithic times. Yet, the much larger formation of Gabellotto Gorge obsidian was almost exclusively used, with tiny amounts (1\% to 3\%) of Canneto Dentro obsidian recognized in assemblages outside the Aeolian Islands. The repertoire was very limited, consisting of wide pressure-flaked blades and derivative materials (flakes, used cores, debitage) and microblades and microflakes (Tykot et al. 2013; Freund et al. 2015). The general impression after handling artifacts from several assemblages (Table 1) is that anything sharp enough to cut was appreciated (Figure 2), even if it was far too small to be handled directly, and therefore needed hafting. The homogeneity of the typological forms of Lipari obsidian found outside the Aeolian Islands is mirrored by inconsistency in the color, transparency, and presence of phenocrysts across the assemblages. It seems that no physical characteristic mattered and this is to be expected given that many obsidian artifacts were unlikely to be used in direct contact with the hand or could represent the most visible part of any tool, including the simplest of handles. These were not artifacts designed to be seen, rather they were specifically selected for their sharpness as functional tools. This is in contrast with the use of obsidian in other regions, such as Anatolia, where obsidian was also appreciated for its physical characteristics and employed in ornaments (Healey \& Campbell 2014).

The trend in the production of obsidian tools is towards a production and appreciation for smaller, thinner blades in the Copper Age (Freund et al. 2017), although differences are negligible and probably represent a greater confidence, in time, knapping this glassy stone to the intended size, which was relatively small from the beginning. It is possible that local people, helped by seasonal migrants from nearby lands, produced the cores (Figure 3) for exchange. Some blades were certainly produced in Lipari and exchanged ready to use, but prepared cores must have become an important export already in the Middle Neolithic. It appears to have been a staged re-distribution operated by specialist merchants and local artisans. The presence of intermediaries acting as merchants is revealed by the very long range of distribution of Lipari obsidian, its preference over other sources, and the requirement for several redistributive centers, where obsidian worked in cores was received, then transformed in blades and flakes, and also exported in the surroundings. The raw material was always easily accessible, and with the forming of regional exchange networks in the Neolithic, it was more easily and widely transported. Thus, there appears to have been no effort to increase the size of the blades even if possible. It is likely that the use of obsidian in combination with some other tools allowed minimalist artifacts to be perfectly suited for their intended use. This explicit connection with a working tool and the deriving difficulty for users to appreciate some of the visual qualities of obsidian when mounted on a tool, made obsidian present in the archaeological record, but almost invisible in daily life. The evidence for all huts with obsidian, such as those at Piani della Corona, near Reggio Calabria (personal communications with Elena Natali in May 2016), makes clear that obsidian was scattered broadly in the floors of the huts, the external surface and was naturally collected in pits and canals by the flowing of water, even just rain. The bags, boxes, and bowls in which it is found 
in modern museums are often deceiving, because they suggest a high visibility or separation of the artifact from other lithics and artifacts. In a few cases cores from raw obsidian are found in centers for local working and redistribution, and these assemblages together with the cargoes of traveling obsidian were the only contexts in which obsidian was prominently visible and distinct from other materials.
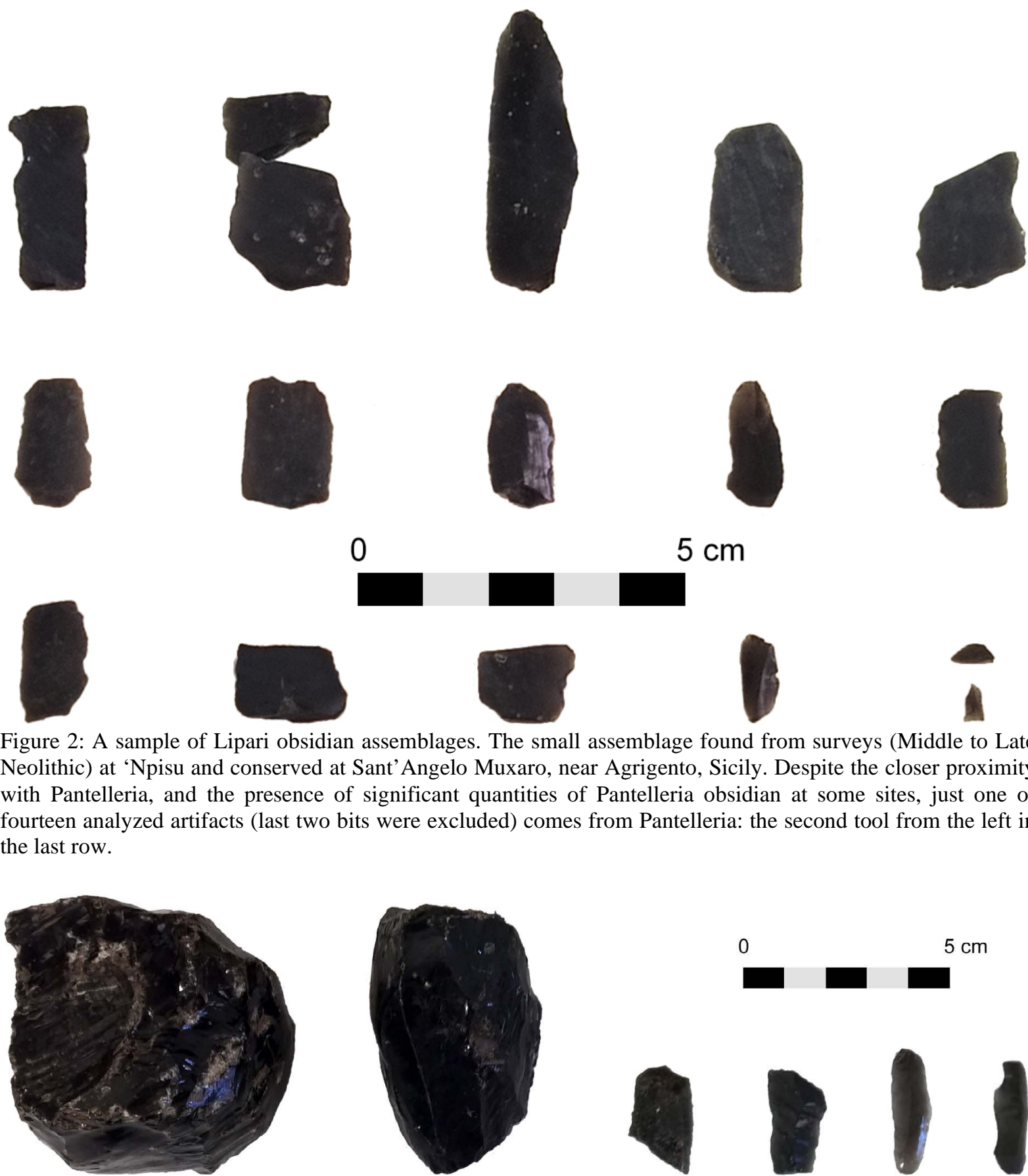

0
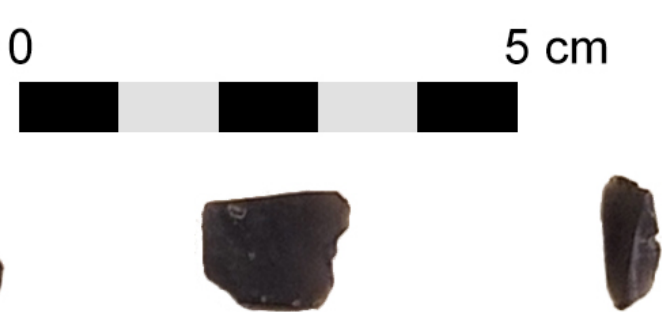

Figure 2: A sample of Lipari obsidian assemblages. The small assemblage found from surveys (Middle to Late Neolithic) at 'Npisu and conserved at Sant'Angelo Muxaro, near Agrigento, Sicily. Despite the closer proximity with Pantelleria, and the presence of significant quantities of Pantelleria obsidian at some sites, just one of fourteen analyzed artifacts (last two bits were excluded) comes from Pantelleria: the second tool from the left in the last row.
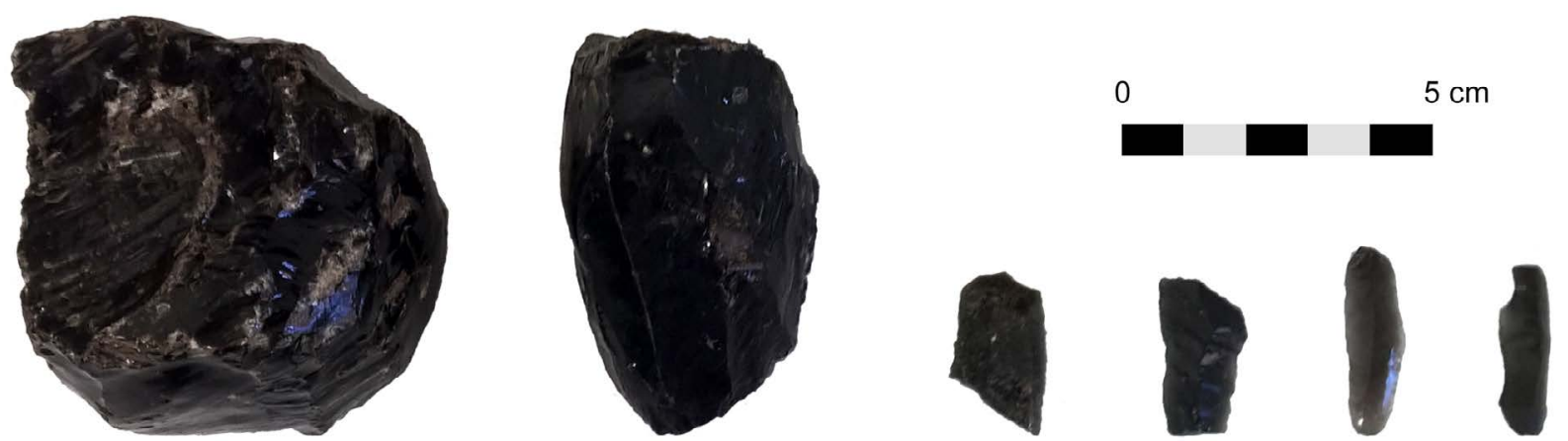

Figure 3: Artifacts from San Leonardo di Cutro, near Crotone, Calabria. Prepared cores (see particularly the second artifact from left for a core partially used to produce blades as those to the right) are frequent in Calabria, unlike Sicily.

The nearly absolute absence of indigenous types merits further consideration. Given the broad range of distribution of Lipari obsidian since the Early Neolithic, it comes to no surprise that areas with different lithic traditions were interested by the exchanges. Yet, no 
evidence has emerged that different obsidian artifacts were requested or produced locally to suit the indigenous traditions, with the sole exception of arrowheads, known in a few sites in Calabria in very modest quantities (less than 10 in all cases), and so far at just one Sicilian site. The arrowheads are very distinctive and seem to follow an established lithic tradition, particularly the Calabrian tradition centered on the Acconia plain and known on the Tyrrhenian side of Calabria down to the Strait of Messina. The plain is the region where most such artifacts were recovered. There is also a strong tradition of lithic arrowheads produced in distinctive shapes and bright colors in Sicily, as visible today in the collections of the museums of Sant'Angelo Muxaro, but arrowheads in obsidian are absent despite over a century of painstaking surveys by private residents and archaeologists, which have found the usual blades in Lipari obsidian even in remote valleys. Absence of evidence in this case should be accepted as evidence that only blades were produced for export.

It is not possible at present to identify the specific use of tools made of obsidian, but an important clue is provided by the significant reduction in the circulation of obsidian from the Copper Age to the Middle Bronze, when effectively its use ends. This reduction seems to be more marked in the fringes of the distribution area, i.e. everywhere but Sicily and Calabria, the two regions closest to Lipari. During this period, there is the introduction of metals in the area, quite slow and in the opposite direction of obsidian distribution, from the north and east to the south-west corner formed by Calabria and Sicily, and last to Malta, just beyond Sicily. Since both small blades and flakes are very sharp and effective in cutting and slicing, it is possible that these activities were only progressively replaced by copper-based metals, which can be more easily adapted to functional forms. Some of the earliest metals in Sicily and Calabria are pins, beads and decorative artifacts, which would be consistent with the slow introduction of metals, and apparent replacement of obsidian. Obsidian was used as grave goods in the Neolithic period. Small used blades (sometimes there is evidence of retouch, which is typical of heavy use), angular waste and flakes were part of assemblages in Sicily. These artifacts are obviously not particularly nice to see, but nonetheless they must have been valuable, even if they are not concentrated on the wealthiest tombs. It seems that showing access to obsidian and the possibility to discard some was an early indicator of wealth and social status, but in these regions social hierarchy was minimal even during the Bronze Age, and it was the occupation in life to mark the importance of people. Having a rock-cut tomb and some grave goods, no matter how modest they appear to us, was by itself an indicator of wealth and a solid position in the local community. This leads to the conclusion that obsidian was valuable and its use, even if purely functional, demonstrated some important active role in society.

\section{Function}

Determining the function of obsidian requires more studies, but it is nonetheless important to present a few considerations. The obvious use for a cutting tool introduced in the Neolithic and probably later replaced by copper-based metals would have been cutting plants, linking obsidian to agriculture. Obsidian sickles are known in the ancient Near East, but this does seem the case here. Instead, obsidian artifacts may have been used for threshing in agriculture and slicing hides in tanning industries, which are secondary processes carried on outside the fields, and for this reason perhaps understood as more advanced or associated with the finished goods. Basalt sickles were equally effective, and both chert and basalt were widely accessible (in Sicily, basalt lithics is predominant, while in Calabria chert is widespread, all sites studied are never far from both sea and mountains). Basalt and chert lithics in Sicily dominate assemblages despite the research focus on obsidian (Martinelli 2009). The scattered presence in settlements provides a strong hint that obsidian was indeed 
used for manufacturing or secondary processes in the settlements. A comprehensive study on the group of small assemblages of obsidian found in eastern Spain, consisting of Sardinian obsidian and all small blades, concluded that, "the use-wear analysis of the blade tools shows their use in everyday tasks", which is most likely related to cutting "plant and soft materials" (Terradas et al. 2014: 75-76). This conclusion contrasts with the finding that, "pressure flaked obsidian bladelets were used for cutting soft animal tissue" in Mesopotamian contexts with multiple types of tools (Ibáñez et al. 2007: 162). Population density, craft specialization and the scale of agricultural production may have been different between the two areas, but pressure flaked retouch is consistently absent in Italian obsidian and can be a deliberate choice. Comparative studies cannot provide a solution, but it is likely that the general conclusions for the Iberian assemblage, suggesting different uses for the same type of blade, are valid for Lipari obsidian and are consistent with preliminary data from use-wear data (personal communications with M. R. Iovino in 2016).

Whilst it is not yet possible to prove directly or make a convincing case for the function of obsidian during the Neolithic (Tinè 2001), the case of its replacement with metals in the Bronze Age is strong. The main site in Sicily where metals appeared in significant quantities, with evidence of metalworking and later scrap metal hoards for recycling, is Lipari. There is no reason for this even invoking exchange networks: Lipari needed almost everything and only had obsidian, and could sustain in prehistory only a small population. The island is also accessible within one day of navigation from both Sicily and Calabria, but the two can be linked directly in the same way and there are plenty of peninsulas and islets that could have been used as safe harbors as was the case for Ognina (Siracusa), linked with Malta, and Thapsos, linked with Calabria, Apulia and the Aegean world. Milazzo, the nearest harbor to Lipari, is a peninsula and could be reached directly from Calabria as well. Thus, the choice of Lipari, where there was already a successful industry (obsidian) that could not move somewhere else, suggests that the people in Lipari continued to maintain their exchange network and metals were introduced not to compete against obsidian, as cutting tools, but either as a complementary commodity or a replacement one. Lipari residents visiting the mainland could have acquired some copper-based metal objects or possibly ingots and brought it back, as well as exchanged with visitors to the island. There may have been extended family relations between residents on Lipari with some in Milazzo.

The use of obsidian for cutting hides opens up also the possibility that it was used for body modifications, especially for shaving or marking the body. Tattooing in particular was known in the Italian peninsula, as the Copper Age mummy Ötzi proves (Samadelli et al. 2015), and obsidian is known to have been used for such activities in Melanesia (Kononen 2012). The technique used, at least for some markings, is the production of parallel lines by incisions into which charcoal was rubbed. The use for shaving and marking the body is highly speculative, but in fact there is no other tool that was sharper than glassy obsidian, and if these activities were practiced (trimming of hair, shaving, tattooing, etc.), then obsidian would have provided the best material.

There is indeed the problem of longevity in the use of obsidian, which is unexpected given that by the Copper or Early Bronze Age copper-based metals were available and circulating everywhere in Italy, and yet obsidian continued circulating. If obsidian was only used as part of a technological package connected with agriculture, and for this reason quickly adopted, then the arrival of a better technology should follow the same process, albeit depending on availability and relative cost. The archaeological record suggests that this indeed happened, but accounted only for a reduction of the exchanged obsidian material, and the pattern of use remained homogenous across the territory (i.e. there is no progressive replacement across the territory, with areas of early adopters, just a reduction across the board). Obsidian blades as razors and other cutting tools are not the only possibility, since 
obsidian could have maintained some traditional role in particular manufacturing industries, especially related to tanning hides. The relatively small dimensions of blades are problematic in deciphering what obsidian was used for, given that obsidian tools were almost certainly part of some complex tool. Yet, obsidian was almost certainly used for precision work, particularly precise or small cuts, and may have been employed for highly specialized or particular jobs, such as cutting the umbilical cord of babies at birth (personal communications with Keri Brown in July 2015). Of course, the primary use, particularly during the Neolithic, is on activities related to agriculture, but these cannot explain all evidence.

\section{Exchange networks}

The preference for Lipari obsidian over other sources in southern Italy, and the nearly exclusive use of obsidian from Gabellotto Gorge (ca. 97\%) implies a pattern of substantial organization and collaboration since the earliest times. There are two distinctive patterns that can be detected (at this stage of the research we can suggest the eastern coast of Sicily - with few cores - and Calabria - with many cores - as recognized examples). Traveling artisans were responsible for the production of obsidian tools, with a system that promoted the preparation of cores at Lipari ready for detaching blades on location. It may be possible that these people were traveling to and from Lipari to work in the Lipari obsidian industry. The population of Lipari probably varied seasonally and annually, since subsistence on the island has been problematic for the entire prehistoric period. Few knappers may have been skilled or confident with obsidian, which requires different skills for knapping than flint/chert, basalt, and quartzite (the vitreous obsidian in small blades and flakes not only requires greater precision in hitting the core, but is also extremely sharp to handle), and this coastal area was large enough to satisfy the needs of the obsidian industry in Lipari. The distinguishing pattern is suggestive of some particularity. The exclusive use of Lipari obsidian along the coast southwards to Syracuse is unique: north-west in the Palermo area Pantelleria obsidian arrived in statistically significant quantities, as well as in Malta. The absence of unworked or partly worked cores implies frequent provisions from the source and a method of distribution that assumed guaranteed access to Lipari. Combining the observations (see Nicoletti 2001), the most likely solution is that the traveling artisans of this area were also the artisans on Lipari, or at least trained in Lipari or by people from Lipari. The geographic position of Lipari and tight control of the exchange network suggests that Lipari was the production center of obsidian both for acquiring it and working it, even if the know-how of working it could have spread in later times reducing any chance of controlling it, but it looks like the know-how radiated from Lipari and many connections, at least for sourcing the material, must have been in place for long. In Calabria (Ammerman \& Andrefsky 1982; Ammerman \& Polglase 1993; Robb 2007), substantial numbers of cores were brought to specific sites during the Middle and Late Neolithic (at least), where they were transformed into blades then re-distributed in a capillary way to smaller sites. Farther away, in central and northern Italy, movements across the network were less intense and distances greater, and local artisans took charge of working obsidian.

Lipari dominates the distribution of obsidian to a vast area over the Palmarola and Pantelleria obsidian sources, likely due to its high quality and being equally or more easily accessible, while patterns of consumption do vary in time and region by region. This is clearly the case in the Near East, where obsidian was usually procured from multiple sources (e.g., Chabot et al. 2008: 154; Yellin \& Garfinkel 1986: 102; Nishiaki 1993), and there were significant changes in patterns by site and period (e.g., Schechter et al. 2013; Garfinkel 2011), with evidence of cultural choices by people (Maeda 2011). Merchants provided a prepackaged product (in the form of cores), ready to use, large quantities, and regular supply, in 
what can be described as monumental economy (Robb 2004). Complex networks of interaction have now been recognized in the Near East by using mathematical modeling (Ibáñez et al. 2015) and detecting major redistribution centers such as at Tell Labwe South, Lebanon (Khalidi et al. 2013).

\section{Conclusions}

The industry based on Lipari obsidian has proved particularly unusual for the technical homogeneity of its products, preference for obsidian from Gabellotto Gorge, and a broad range of distribution. It is always very difficult to report with only preliminary or partial data available, since different scenarios could be plausible, but it suffices to say here that the archaeological record determined this fundamental conclusion. Unpublished data from the ongoing systematic survey of materials carried out by the authors substantiate the conclusions (see Table 1 for a list of sites). Most archaeological obsidian tools recovered from surveys and excavations have been seen, and comprehensive obsidian sourcing studies have been conducted in Sicily (see also Boscaino et al. 2012; Papallardo et al. 2013; Foresta Martin et al. 2017). There appears to have been technological homogeneity in obsidian for the majority of materials in Calabria and Sicily, and many from other regions. Nevertheless, Sardinian and Palmarola artifacts have been found at sites in Campania and Molise (Table 1), but are nearly absent in Calabria. The almost exclusive use of the Gabellotto Gorge source is also shown by extensive pXRF analyses (Tykot et al. 2013; Freund et al. 2015).

The presence of regional exchange networks, each linked with other similar networks operating on the territory of material cultures and styles, usually determined by typological analyses on pottery for the Italian Neolithic period, has been a staple of interpretations. An exchange network was built early in the Neolithic. Obsidian could have been produced in some quantity and transported far away in an organized manner, using different approaches (e.g., traveling artisans by sea with cores and redistribution over land of blades from cores worked at major centers). The product was standardized (small-to-modest sized blades) and made available so efficiently that it competed successfully with that of Pantelleria and Palmarola obsidian, even at sites geographically close to these sources. The geography of Italy, being a peninsula surrounded by large and small islands, certainly alleviated the need for ships built for open seas, a development of the Bronze Age, but the hardship and constraints in traveling far, even just circumnavigating Calabria from the mid-Tyrrhenian coast facing Lipari to the northern Ionian coast on the other side would have proved long, daunting, grueling, and uncertain. Yet, the archaeological record and inferable distribution system is the same from Calabria to Apulia, including the large quantities of obsidian transported. Thus, individual merchants may have crossed the Tyrrhenian, Ionian and Adriatic Seas in single voyages. This kind of voyages allowed people to exchange their product with flexible terms, quite differently from barters of needed products that would be expected in the Neolithic. The key difference is that value was variable because of uncertainties in the local scale of values or availability of alternative commodities and the need to obtain enough exchanged products to warrant a return voyage. Overland routes from coastal areas also existed and added greater complexity to the exchange network, particularly in territories farther from Lipari and in areas where other exchange networks operated.

Prehistoric merchants were not attempting to sell a product to make a profit in the modern sense, where the desire to have a surplus and increase it is dominating, rather these particular merchants happened to have a disproportionate amount of a valuable commodity, but little else, and needed much ingenuity to make a living. To them, losing a cargo of glassy obsidian may have been less tragic than losing a ship such as the Late Bronze Age Uluburun shipwreck in Turkey, famed for its riches, because their cargo could have been easily 
replenished in Lipari, motivating people to take risks. They needed to obtain other commodities however, and that meant trying to make the most of their product, and protect the distribution network they were building to ensure that year after year they could continue to support themselves the same way.

The end result is a sophisticated market economy (intended as a flexible economy founded on demand and supply rather than barters), which may be most similar to our contemporary international crude oil trade (An et al. 2015; Yang et al. 2015), a necessity for most, and yet a commodity disproportionally concentrated in a few locations. Its value depends on several variables, some quite artificial such as availability, political decisions, international sanctions, so much that international governmental organizations tasked with controlling it, such as OPEC, have limited influence (Colgan 2014). And access to it provokes dependency in the form of industries needing its derivate energy to operate, and therefore a modern country simply cannot avoid purchasing it without harming its society. Lipari obsidian may have been in principle very similar, a commodity useful, and eventually needed for some activities and manufacturing industries, producing a dependency in antiquity because of the large volumes of material available, which made it all but rare, and indeed unsuitable for decoration as it was not considered exotica, a desirable and valuable material (Vianello 2011; Tykot 2011). The same is true for the parallel with oil: it is highly valuable and often coming from far away, but it is also a staple for some industries and ubiquitous in its various forms. International politics was certainly not part of ancient exchange, but decisions to value it differently, perhaps lower in case of possible competition, and strategic decisions to follow certain routes to establish or maintain dominance in the procurement of obsidian, may have well altered its value and availability, swaying artificially decisions to consume obsidian towards Lipari obsidian. We stress here that the "production" of obsidian tools required a modest effort in terms of time and labor as compared to raising a cow or farming a plot of land, and therefore this was a special case where any theoretical model based on production and consumption fails because of the discrepancy and variability in value of the product. A parallel with modern markets is more effective, as long as it is understood that this was a special case of a naturally occurring raw material in a suitable geographic region.

The ultimate objective was to guarantee the subsistence of the people involved in distribution and exchange and their families, as it was the case for any other person at the time. The rules to achieve this were however different with Lipari obsidian, an island more centrally located than Pantelleria, too small to support an internal market of any significance as it was the case for Sardinia, and inhabited most of the time, unlike the never settled Palmarola, with easy access to a very high quality, glassy obsidian. There lies the particularity of Lipari, which was an island with much obsidian, a small but active population, and an excellent location for exchanges: obsidian was the most abundant and valuable of products that the people in Lipari could have, probably a very important reason that attracted people in the first instance. During the Middle to Late Neolithic, a large part of the population may have worked in function of the exchange of obsidian, and that may have provoked the evidence of centrality and of a mostly single organization: obsidian mainly was controlled by a tight community. Nevertheless, the socioeconomics and other variables of Neolithic distribution and exchange were not fixed and uniform, with activity undoubtedly at the household level, as well as by traders and other visitors from Sicily and Calabria.

Future research will target the few sites formally excavated to establish a more precise chronological subdivision of its production and exchange. But the general conclusions proposed here cannot be changed significantly, because in nearly all sites we encountered small blades or prepared cores for producing small blades, almost exclusively from Lipari, and there is no context or period that seems in any way distinct. Only between the Early and 
Middle Bronze Age does the flow of obsidian significantly reduce and eventually cease. Lithics other than obsidian also need some review - obsidian tools are a minority of lithic assemblages everywhere but in the Aeolian Islands - but we find only rarely tools as sharp or typologically similar to the standardized obsidian small blade.

\section{References}

Ammerman, A. J. \& Andrefsky, W., Jr. 1982, Reduction sequences and the exchange of obsidian in Neolithic Calabria. In: Contexts for Prehistoric Exchange (Ericson, J. E.; Earle, T. K., Eds.), Academic Press, New York: p. 149-172.

Ammerman, A. J. \& Polglase, C. 1993, The exchange of obsidian at Neolithic sites in Italy. In: Trade and Exchange in Prehistoric Europe (Scarre, C.; Healy, F., Eds.), Oxbow Books, Oxford: p.101-108.

An, H., Zhong, W., Chen, Y., Li, H. \& Gao, X. 2014, Features and evolution of international crude oil trade relationships: A trading-based network analysis. Energy, 74: 254-259. doi:10.1016/j.energy.2014.06.095

Bacci, G.M. 2009, Introduzione storica. In: Guida archeologica delle Isole Eolie, Soprintendenza ai Beni Culturali e Ambientali di Messina, Regione Siciliana, Palermo: p. 11-18. (in Italian) ("Historical introduction”)

Boscaino, A.; D'Amora, A.; Nicoletti, F.; Trifuoggi, M.; Tusa, S., 2012, Indagini sulla caratterizzazione e la provenienza delle ossidiane di Serra del Palco (CL). In: Atti della XLI riunione scientifica: dai ciclopi agli ecisti società e territorio nella Sicilia preistorica e protostorica, Istituto Italiano di preistoria e protostoria, San Cipirello (PA): p. 569-578. (in Italian) ("Investigations on chemical composition and provenance of the obsidian tools from Serra del Palco”)

Chabot, J., Badalyan, R. \& Chataigner, C. 2008, A Neolithic obsidian industry in the southern Caucasus region: Origins, technology and traceology. In: Proceedings 36th international symposium on archaeometry (Moreau, J.-F., Auger, R., Chabot, J. \& Herzog, A., Eds.), Centre interuniversitaire d'Études sur les Lettres, les Arts et la Tradition (CELAT), Université Laval, Québec City: p. 151-160.

Colgan, J.D. 2014, The emperor has no clothes: the limits of OPEC in the global oil market. International Organization, 68(03): 599-632. doi:10.1017/S0020818313000489

Foresta Martin, F., Di Piazza, A., D’Oriano, C., Carapezza, M.L., Paonita, A., Rotolo, S.G. \& Sagnotti, L. 2017, New insights into the provenance of the obsidian fragments of the island of Ustica (Palermo, Sicily). Archaeometry, 59(3): 435-454. doi:10.1111/arcm.12270

Freund, K.P. 2014, A Multi-Scalar Analysis of the Politics of Obsidian Consumption in the West Mediterranean (ca. 6th - 2nd millennia B.C.). Unpublished $\mathrm{PhD}$ thesis at the Anthropology Department, McMaster University, Hamilton, 337 p.

Freund, K.P., Tykot, R.H. \& Vianello, A. 2015, Blade production and the consumption of obsidian in Stentinello period Neolithic Sicily. Comptes Rendus Palevol, 14(3): 207217. doi:10.1016/j.crpv.2015.02.006

Freund, K.P., Tykot, R.H. \& Vianello, A. 2017, Contextualizing the role of obsidian in Chalcolithic Sicily (c. 3500 - 2500 BC). Lithic Technology, 42: 35-48. doi:10.1080/01977261.2017.1290335 
Garfinkel, Y. 2011, Obsidian distribution and cultural contacts in the southern Levant during the 7th millennium cal. BC. In: The State of the Stone Terminologies, Continuities and Contexts in Near Eastern Lithics (Healey, E., Campbell, S. \& Maeda, O., Eds.), Ex Oriente, Berlin: p. 403-410.

Healey, E. \& Campbell, S. 2014, Producing adornment: Evidence of different levels of expertise in the production of obsidian items of adornment at two late Neolithic communities in northern Mesopotamia. Journal of Lithic Studies, 1(2): 79-99. doi:10.2218/jls.v1i2.966

Ibáñez, J.J., Urquijo, J.G. \& Rodríguez Rodríguez, A. 2007, The evolution of technology during the PPN in the Middle Euphrates: A view from use-wear analysis of lithic tools. In: Systèmes techniques et communautés du Néolithique précéramique au ProcheOrient (Astruc, L., Binder, D. \& Briois, F., Eds.), Éditions APDCA (Association pour la Promotion et la Diffusion des Connaissances Archéologiques), Antibes: p. 153-165.

Ibáñez, J.J., Ortega, D., Campos, D., Khalidi, L. \& Méndez, V. 2015, Testing complex networks of interaction at the onset of the Near Eastern Neolithic using modelling of obsidian exchange. Journal of the Royal Society Interface, 12(107). doi:10.1098/rsif.2015.0210

Kaul, F. 1998, Ships on Bronzes: A Study in Bronze Age Religion and Iconography. Publications from the National Museum. Studies in Archaeology \& History, Series 3, Vol. 1. National Museum of Denmark, Copenhagen, 296 p.

Khalidi, L., Gratuze, B., Haidar-Boustani, M., Ibáñez, J.J. \& Teira, L. 2013, Results of geochemical analyses of obsidian artefacts from the Neolithic site of Tell Labwe South, Lebanon. In: Stone Tools in Transition: From Hunter-Gatherers to Farming Societies in the Near East (Borrell, F., Ibáñez, J.J. \& Molist, M., Eds.), Universitat Autònoma de Barcelona, Barcelona: p. 475-494.

Kononen, N. 2012, Middle and Late Holocene skin-working tools in Melanesia: Tattooing and scarification? Archaeology in Oceania, 47(1): 14-28. doi:10.1002/j.18344453.2012.tb00111.x

Le Bourdonnec, F.-X., Poupeau, G., Boussofara, R., Dubernet, S., Moretto, P., Compin, M. \& Mulazzani, S. 2015, Obsidians from the Kerkennah Islands (eastern Tunisia) and the PIXE elemental compositions of the Mediterranean peralkaline obsidians. Nuclear Instruments and Methods in Physics Research Section B: Beam Interactions with Materials and Atoms, 358: 271-275. doi:10.1016/j.nimb.2014.04.028

Leighton, R. 1999, Sicily before History: An Archaeological Survey from the Palaeolithic to the Iron Age, Bristol Classical Press, Bristol, 312 p.

Longo, L., Iovino, M.R. \& Lemorini, C. 2000, L'analisi funzionale per lo studio delle industrie litiche. Con un'appendice sull' analisi funzionale delle materie dure animali. Rivista di Scienze Preistoriche, 51: 389-454. (in Italian) ("The functional analysis for the study of lithic industries. With an appendix on the functional analysis of hard materials of animal origin”)

Maeda, O. 2011, The social roles of the use of flint and obsidian artefacts at Salat Cami Yanı in the upper Tigris valley. In: The State of the Stone: Terminologies, Continuities and Contexts in Near Eastern Lithics. Studies in Early Near Eastern Production, Subsistence, and Environment 13 (Healey, E., Campbell, S. \& Maeda, O., Eds.), Ex Oriente, Berlin: p. 317-326. 
Martinelli, M.C., 1995, L'industria litica di Rinicedda. In: Meligunis Lipara VIII Salina ricerche archeologiche (1989-1993) (Bernabò Brea, L. \& Cavalier, M., Eds), Accademia di Scienze, Lettere e Arti, Palermo: p. 167-182. (in Italian) ("The lithic industry of Rinicedda”)

Martinelli, M.C., 2009, Le asce-martello e altri manufatti in pietra levigata conservati nel Museo di Adrano. In: Tra Etna e Simeto. La ricerca archeologica ad Adrano e nel suo territorio. Atti dell'incontro di studi per il 50 anniversario dell'Istituzione del Museo di Adrano, Adrano, 8 giugno 2005 (Lamagna, G. Ed.), Biblioteca della Provincia Regionale di Catania, Catania: p. 69-73. (in Italian) ("The hammer-axes and other lithic tools conserved in the Adrano Museum”)

Nicoletti, F., 2001, Il commercio prestorico dell'ossidiana nel Mediterraneo ed il ruolo di Lipari e Pantelleria nel più antico sistema di scambio. In: Preistoria: Dalle coste della Sicilia alle Isole Flegree: Saggi (Tusa, S., Ed.), Arnaldo Lombardi Editore, Palermo: p. 259-270. (in Italian) ("Prehistoric trade of obsidian in the Mediterranean and the role of Lipari and Pantelleria in the most ancient exchange system")

Nishiaki, Y. 1993, Anatolian obsidian and the Neolithic obsidian industries of north Syria: A preliminary review. In: Essays on Anatolian Archaeology, Vol. 7 (Mikasa, T., Ed.), Harassowitz Verlag, Wiesbaden: p. 140-160.

Pappalardo, L., Romano, F. P., Bracchitta, D., Massimino, A., Palio, O. \& Rizzo, F. 2013, Obsidian provenance determination using the beam stability controlled BSC-XRF and the PIXE-alpha portable spectrometers of the LANDIS laboratory: the case of Via Capuana settlement in Licodia Eubea (Sicily). Journal of Geophysics and Engineering 10: 1-12. doi:10.1088/1742-2132/10/6/064004

Robb, J., 2004, The extended artefact and the monumental economy: A methodology for material agency. In: Rethinking Materiality: The Engagement of Mind with the Material World (DeMarrais, E.; Gosden, C.; Renfrew, A. C., Eds.), McDonald Institute for Archaeological Research, Cambridge: p. 131-139.

Robb, J., 2007, The Early Mediterranean Village: Agency, Material Culture, and Social Change in Neolithic Italy, Cambridge University Press, Cambridge, 406 p.

Samadelli, M., Melis, M., Miccoli, M., Vigl, E.E. \& Zink, A.R. 2015, Complete mapping of the tattoos of the 5300-year-old Tyrolean Iceman. Journal of Cultural Heritage, 16(5): 753-758. doi:10.1016/j.culher.2014.12.005

Schechter, H., Marder, O., Barkai, R., Getzov, N. \& Gopher, A. 2013, The obsidian assemblage from Neolithic Hagoshrim, Israel: Pressure technology and cultural influence. In: Stone tools in transition: From hunter-gatherers to farming societies in the Near East (Borrell F., Ibáñez, J.J. \& Molist, M., Eds.), Universitat Autònoma de Barcelona, Servei de Publicacions, Bellaterra, Barcelona: p. 509-528.

Terradas, X., Gratuze, B., Bosch, J., Enrich, R., Esteve, X., Oms, F.X. \& Ribé, G. 2014, Neolithic diffusion of obsidian in the western Mediterranean: New data from Iberia. Journal of Archaeological Science, 41: 69-78. doi:10.1016/j.jas.2013.07.023

Thorpe, O.W., Warren, S.E. \& Courtin, J. 1984, The distribution and sources of archaeological obsidian from southern France. Journal of Archaeological Science, 11(2): 135-146. doi:10.1016/0305-4403(84)90048-7 
Tinè, S., 2001, Il neolitico della Sicilia da un punto di vista peninsulare. In: Preistoria: Dalle coste della Sicilia alle Isole Flegree: Saggi (Tusa, S., Ed.), Arnaldo Lombardi Editore, Palermo: p. 275-280. (in Italian) ("Sicilian Neolithic from a peninsular perspective”)

Tykot, R.H. 2011, Obsidian finds on the fringes of the Central Mediterranean: Exotic or eccentric exchange? In: Exotica in the prehistoric Mediterranean (Vianello, A., Ed.), Oxbow Books, Oxford: p. 33-44.

Tykot, R.H. \& Ammerman, A.J. 1997, New directions in central Mediterranean obsidian studies. Antiquity, 71(274): 1000-1006. doi:10.1017/S0003598X00085896

Tykot, R.H., Iovino, M.R., Martinelli, M.C. \& Beyer, L. 2004, Ossidiana da Lipari: le fonti, la distribuzione, la tipologia e le tracce d'usura. In: Atti Della XXXIX Riunione Scientifica. Materie Prime E Scambi Nella Preistoria Italiana, Istituto italiano di preistoria e protostoria, Florence: p. 592-597. (in Italian) (“Obsidian from Lipari: sources, distribution, typology and use-wear”)

Tykot, R.H., Freund, K.P. \& Vianello, A. 2013, Source analysis of prehistoric obsidian artifacts in Sicily (Italy) using pXRF. In: Archaeological Chemistry VIII (Armitage, R.A. \& Burton, J.H., Eds.), ACS Symposium Series Vol. 1147, ACS Publications, Washington, DC: p. 195-210.

Vianello, A., (Ed.), 2011, Exotica in the Prehistoric Mediterranean. Oxbow Books, Oxford, $216 \mathrm{p}$.

Yang, Y., Poon, J.P.H., Liu, Y. \& Bagchi-Sen, S. 2015, Small and flat worlds: A complex network analysis of international trade in crude oil. Energy, 93(1): 534-543. doi:10.1016/j.energy.2015.09.079

Yellin, J. \& Garfinkel, Y. 1986, The source of archaeological obsidian from a Pre-Pottery Neolithic B site at Yiftahel, Israel. Paléorient, 12(2): 99-104.

doi:10.3406/paleo.1986.4412 